\title{
ODOUR CONTROL STRATEGIES FOR A SUSTAINABLE NUISANCES ACTION PLAN
}

\author{
FASOLINO I. ${ }^{1}$ \\ GRIMALDI M. ${ }^{1}$ \\ ZARRA T. ${ }^{1}$ \\ NADDEO $V^{1}$
}

Received: 25/08/2016

Accepted: 07/09/2016

Available online: 12/10/2016

\author{
${ }^{1}$ Università degli Studi di Salerno \\ Department of Civil Engineering
}

Sanitary Environmental Engineering Division (SEED)

Via Giovanni Paolo II, 132, 84084 Fisciano (SA), Italy

*to whom all correspondence should be addressed: e-mail: tzarra@unisa.it

\section{ABSTRACT}

Different land uses, infrastructures, industrial activities and residential patterns of developed cities expose simultaneously people to several annoying sources.

Over recent years, the European Union has provided several tools to harmonize noise mapping methodologies and relative Noise Action Plans through directives. Unfortunately, the same effort has not been made for the harmonization of approaches of other annoying sources such as odours. As a consequence, each European Member State has defined its own direct or indirect approach to limit odour impacts.

The most common approach to deal with noise impact is the use of priority indices to highlight areas that are sensitive to both noise and, generally, odour impacts. The aim of the present research is to provide a brief review of the most widely used European strategies in noise action plans as well as try to extend the approaches to the definition of a nuisance action plan, capable of controlling both odour and noise.

The analysis underlines that is possible to define the degree of sensitivity of areas according to population, land uses, levels of exposures and/or distance from the annoying sources. Nuisance acceptability levels are then definable according to the sensitivity degree of the locations.

Keywords: annoyance, environmental nuisances, land use planning, noise.

\section{Introduction}

Many economic activities and land uses emit levels of odour and/or noise to the atmosphere that have the potential to compromise the livability at a local or regional scale (Zarra et al., 2008; Zarra et al., 2010). In developed cities, this can often be an actual nuisance for communities and residents, especially those who are downwind from specific plants and/or activities (composting facility, wastewater treatment plant, fast food, restaurant, traffic, animals, solid waste management, etc.). Complaints resulting from the impacts of such emissions are common (Belgiorno et al., 2012; Zarra et al., 2009a) and the task of ensuring that development proposals are compatible with neighbouring land uses is a responsibility of regulatory authorities. Complaints often bring legal problems and, in some cases, can even lead to the suspension of operations or even closure of the facility (Zarra et al., 2009b).

There are different definitions of noise and odour annoyance, but the most common view of both is that they are indicators of nuisance, disturbance or disruption to intended or actual activities (Griffiths, 2014; Guski et al., 1999; Naddeo et al., 2012a). 
Place and environmental context refers to the unique combination of physical characteristics that influence exposure along with sociocultural characteristics that may influence environmental perceptions in different communities. The understanding how the physical environment influences cumulative exposures can aid environmental management to reduce health risks.

Over recent years, the European Union has provided (and is going to update) several tools to harmonize noise strategies in urban planning through directives and guidelines. Unfortunately, the same effort has not been made for the harmonization of approaches in the standardization of other annoying sources such as odours that actively contribute to the total nuisances of residents. As a consequence, each European Member State at a national, or even local, level has defined its own direct or indirect approach so as to limit and manage odour impacts, with one usually being considerably different from the other (Nicell, 2009; Sironi et al., 2012).

The most common approach to deal with noise impact is the use of priority indices to highlight areas that are sensitive to annoying sources and where mitigation actions are more advisable or urgent. Locations that for their specific land use are more sensitive to noise impacts (e.g. residential areas) are generally also sensitive to odour impacts. Accordingly, the aim of the present research is to provide a brief review of the most widely used European strategies in noise action plans as well as try to extend the approaches for the definition of a nuisance action plan, capable of controlling both odour and noise.

\section{Noise control strategies}

In 2002, the European Union issued an important tool to tackle noise issues with a common approach among all the Member States: the European Directive 2002/49/CE, also called the END (Environmental Noise Directive) (European Union, 2002). The goal of this legislative instrument is "to define a common approach intended to avoid, prevent or reduce on a prioritized basis the harmful effects, including annoyance, due to exposure to environmental noise". To this extent, several actions are needed by each Member State:

- evaluation of the population exposed to high levels of noise (not considering military activities, neighbourhood or occupational noise) by means of noise mapping activities;

- a proper information and communication campaign to increase the awareness of citizens and all the involved stakeholders about noise related effects;

- definition of common strategies to solve or mitigate noise problems and protect quiet areas.

Regarding noise mapping, the European Commission has decided to harmonise the methodologies that the Member States need to adopt by introducing CNOSSOS-EU (Common Noise aSSessment MethOdS) (Kephalopoulos et al., 2014). This common method should be fully operational for the next round of EU strategic noise mapping in 2017.

This section briefly reviews the main indices proposed by researchers, private agencies, public administrations or states to define a sensitivity ranking of the areas where noise can be considered to produce a greater impact. These rankings are commonly used to give priorities to the mitigation measures proposed in the noise action plans of transportation infrastructures or agglomerations, such as the ones required by the END.

In current international literature, it is possible to classify indices that:

- focus on the sound pressure level;

- on the land use (e.g. highest values are reached if schools or hospitals are included in the area);

- on the number of annoyed people and so on.

A brief description of the selected method used for the identification of noise indices is reported in Table 1. 
Table 1. Design characteristics of the investigated LWTPs.

\begin{tabular}{|c|c|c|}
\hline Method & Reference & Brief description \\
\hline $\begin{array}{l}\text { House } \\
\text { depreciation } \\
\text { index }\end{array}$ & $\begin{array}{l}\text { European } \\
\text { Environmental } \\
\text { Agency, } 2010\end{array}$ & $\begin{array}{l}\text { The value of house depreciation in terms of lost } € / d B(A) \text { can } \\
\text { be used as a noise score to rank the buildings that are most } \\
\text { economically affected by noise. }\end{array}$ \\
\hline $\begin{array}{l}\text { Building } \\
\text { Prioritisation } \\
\text { Score (BPS) }\end{array}$ & $\begin{array}{l}\text { Scottish } \\
\text { Government } \\
(2009)\end{array}$ & $\begin{array}{l}\text { This method evaluates the noise exposure of residential } \\
\text { buildings; for each building and for each kind of source (road, } \\
\text { railway and aircrafts) BPS is calculated in function of: } \\
\text { - noise level at the considered building generated by the } \\
\text { considered source; } \\
\text { - the number of address points within the building; } \\
\text { - population per address; } \\
\text { - percentage of people annoyed. }\end{array}$ \\
\hline $\begin{array}{l}\text { Population } \\
\text { Annoyance } \\
\text { Index (PAI) }\end{array}$ & de Ruiter, 2009 & $\begin{array}{l}\text { The method requires assigning each building or dwelling a } \\
\text { noise exposure class }(45-50 \mathrm{~dB}(\mathrm{~A}), 50-55 \mathrm{~dB}(\mathrm{~A}) \text {, etc.) } \\
\text { considering its estimated noise level; then the central value of } \\
\text { the noise class is assigned to each dwelling or building } \\
\text { according to the number of residences. This method takes into } \\
\text { account only exposure to road traffic noise. }\end{array}$ \\
\hline $\begin{array}{l}\text { Multicriteria } \\
\text { matrix }\end{array}$ & $\begin{array}{l}\text { Dublin Local } \\
\text { Authorities, } 2013\end{array}$ & $\begin{array}{l}\text { The method proposes a decision matrix that gives a score to } \\
\text { each area according to: } \\
\text { - noise exposure; } \\
\text { - land use or type of locations (e.g Urban centre, Commercial, } \\
\text { Residential, etc.); } \\
\text { - impacting sources or type of source (e.g. Road, Airport, Rail, } \\
\text { Industry, etc.). }\end{array}$ \\
\hline $\begin{array}{l}\text { Noise Priority } \\
\text { Index }\end{array}$ & $\begin{array}{l}\text { Italian Ministry of } \\
\text { the Environment, } \\
2000\end{array}$ & $\begin{array}{l}\text { The index is calculated for each building and takes into } \\
\text { account: } \\
\text { - number of people affected by noise; } \\
\text { - sensitivity or use of the building (e.g. hospitals, schools, } \\
\text { residential buildings); } \\
\text { - differential between the noise level and the noise limit } \\
\text { characteristics of the area. }\end{array}$ \\
\hline
\end{tabular}

\section{Odour control strategies}

The quality of the air is often affected by chemicals from the everyday activities of industrial and commercial enterprises (Naddeo et al., 2012b) . Exposure to these volatile compounds has become a part of modern day life in urbanized cities. However, residents find the odours annoying as well as objectionable and at some concentration or frequency may declare them a nuisance (Belgiorno et al, 2012; Nicell, 2009; Zarra et al., 2014).

Community odours remain one of the most air pollution complaints to regulators and government agencies. An odour nuisance is usually a result of a series of odour episodes experienced by residents. The frequency of these episodes, the duration of each odour episode, the intensity of the odours and the nature or offensiveness of the odours all contribute to the nuisance experience (Zarra et al., 2012a; Giuliani et al., 2012).

From one region to another, in communities across Europe, as well as in countries, odour issues are addressed by a variety of "odour laws", be they called an ordinance, rule, regulation or policy. The "odour laws" address community odour issues through several approaches that generally use different compliance criteria: 
- annoyance criteria (subjective categories and complaint criteria);

- ambient odour criteria (threshold or intensity);

- ambient odorant criteria (mass concentration of specific substance and/or odour concentration measured in odour unit per cubic meter according to EN 13725:2003);

- episode duration-frequency criteria;

- source emission criteria (threshold or mass concentration) and best available control technology criteria (i.e. industry standard).

Odour assessment tools could be grouped into either predictive or observational/empirical methods (Table 2).

Table 2. Summary of odour assessment tools (adapted by Bull et al, 2014).

\begin{tabular}{|c|c|c|c|c|}
\hline Method & Approach & \multicolumn{2}{|l|}{ Tool } & Indicator \\
\hline \multirow{4}{*}{ Predictive } & Qualitative & \multicolumn{2}{|c|}{$\begin{array}{l}\text { Risk-based assessments using Source- } \\
\text { Pathway-Receptor concept }\end{array}$} & $\begin{array}{l}\text { A relative risk score or descriptor (e.g. } \\
\text { negligible, low, medium or high-risk } \\
\text { impact) }\end{array}$ \\
\hline & Semi-qualitative & \multicolumn{2}{|c|}{$\begin{array}{l}\text { Screening models, look-up tables and } \\
\text { nomographs }\end{array}$} & Estimated concentration \\
\hline & \multirow[t]{2}{*}{ Modelling } & \multicolumn{2}{|c|}{$\begin{array}{l}\text { Atmospheric dispersion modelling } \\
\text { with ADMS, AERMOD, CALPUFF, etc. } \\
\text { using source terms that have been } \\
\text { measured by Dynamic Dilution } \\
\text { Olfactometry (DDO) or using } \\
\text { literature values. }\end{array}$} & $\begin{array}{l}\text { Predicted concentrations (ou } \mathrm{m}^{-3} \text { ), usually } \\
\text { as } 98^{\text {th }} \text { percentiles of } 1 \text {-hour means }\end{array}$ \\
\hline & & CFD tools & & Image representation of flow patterns \\
\hline \multirow{7}{*}{$\begin{array}{l}\text { Observational } \\
\text { /Empirical }\end{array}$} & \multirow{4}{*}{$\begin{array}{l}\text { Monitoring of } \\
\text { odour in } \\
\text { ambient air }\end{array}$} & \multirow[t]{2}{*}{ Sensory } & Sniff Tests & $\begin{array}{l}\text { Odour exposure inferred from } \\
\text { measurements of intensity, frequency, } \\
\text { duration, offensiveness. Draft method } \\
\text { pren264086 is currently going through the } \\
\text { CEN voting process. }\end{array}$ \\
\hline & & & Field Olfactometry & $\begin{array}{l}\text { Odour exposure inferred from measured } \\
\text { concentration (Dilutions-to-Threshold, } \\
\text { similar to (ou } \mathrm{m}^{-3} \text { ), together with } \\
\text { frequency, duration, offensiveness. }\end{array}$ \\
\hline & & \multirow[b]{2}{*}{$\begin{array}{l}\text { Compound } \\
\text { analysis }\end{array}$} & $\begin{array}{l}\mathrm{H}_{2} \mathrm{~S} \text { by gold-film } \\
\text { analyser }\end{array}$ & \multirow{2}{*}{$\begin{array}{l}\text { Odour exposure inferred from measured } \\
\text { concentration }\left(\mu \mathrm{g} \mathrm{m}^{-3}\right) \text { and odour detection } \\
\text { threshold, together with frequency, } \\
\text { duration, offensiveness. However, it can be } \\
\text { difficult to derive a relationship between } \\
\text { concentrations of chemicals and odour } \\
\text { thresholds }\end{array}$} \\
\hline & & & VOCs, etc analysis & \\
\hline & \multirow{2}{*}{$\begin{array}{l}\text { Actively using } \\
\text { the community } \\
\text { as the "sensor" }\end{array}$} & \multicolumn{2}{|c|}{ Odour diaries } & $\begin{array}{l}\text { Days (\%) on which odour detected above a } \\
\text { given intensity }\end{array}$ \\
\hline & & \multicolumn{2}{|c|}{ Community surveys } & $\%$ annoyed or \% experiencing nuisance \\
\hline & $\begin{array}{l}\text { Passively using } \\
\text { the community } \\
\text { as the "sensor" }\end{array}$ & \multicolumn{2}{|c|}{ Complaints analysis } & Frequency of complaints \\
\hline
\end{tabular}

This grouping matches the two main scenarios practitioners will be called on to consider (i.e. a new odour source, or an existing odour source). Each has its own strengths, limitations, and preferred applications. Using tools from both of these categories will usually improve confidence in the conclusions reached.

The observational/empirical tools, by definition, require some form of measurement of ambient odour levels at sensitive receptors local to the source. This is challenging due to: 
- the nature of odour exposure - it is perceived over very short time periods (as short as a few seconds), making most conventional sampling periods (where the sample is averaged over hours to weeks) inappropriate; and

- the difficulty of measuring odour at ambient levels - no analytical techniques can currently match the sensitivity, speed of response and breadth of application of the human nose.

These difficulties influence strongly the choice of tools available to us to directly measure/observe odour levels at receptors. The observational/empirical measurement tools tend to fall into two categories:

- conventional monitoring approach, where the Air Quality Practitioner makes the odour measurements in the field, (e.g. using sniff tests, field olfactometry or chemical compound analysis) (Zarra et al., 2012b);

- community assessment approach, which uses public responses as raw data (e.g. odour diaries, attitude surveys, or complaints monitoring).

It should be noted that it is not possible to monitor ambient odour at receptors as the $98^{\text {th }}$ percentile of 1-hour mean concentrations: concentration benchmarks expressed in this form are designed for use with predictive dispersion modelling, not monitoring.

The various approaches are not mutually exclusive and are sometimes combined in one "odour law". Underlying the approaches to odour laws, there are the basic elements that have been placed into successful regulations of noise action plans.

It is common for jurisdictions to assess the odour impact potential of development proposals by comparing model predicted odour exposure statistics at sensitive receptors against jurisdictional exposure limits or criteria. These criteria are typically specified in the form of a single concentration limit, percentile compliance level and averaging time, which act to limit the intensity and frequency of odour impact events that may be experienced at the receptors.

All these existing approaches are useful in the authorization practices of Local Authorities, for the evaluation of odour impact assessment in EIA, as well as in the case of controlling odour emission with possible sanctions to existing plants. Current "odour laws" generally lack uniformity of assessment and are not used in urban planning.

The assessment tools have been grouped into either predictive or observational/empirical (Table 2). This grouping matches the two main scenarios practitioners will be called on to consider (i.e. a new odour source, or an existing odour source).

\section{Nuisances action plan}

Different definitions, guidelines and laws on both noise and odour have the same receptors that could be subjected to nuisance, disturbance disruption. Odours and noises imply environmental pressures that could cause nuisance to people and ecosystems. The proposition of a Nuisance Action Plan, as an extension of the current and well regulated Noise Action Plan, can provide a complete framework to manage environmental odours and noises as well as control their annoying effects. It also aims to protect quiet and healthy areas in agglomerations (large urban areas), where the quality is good. A proposed framework for the definition of a Nuisance Action Plan is reported in Figure 1 and includes the following steps:

- Assessment of the Degree of Land Sensitivity to Nuisances (S). S degree is calculated for each homogeneous area of the territory and represents its tolerance to nuisance pressures (odour and noise). $S$ degree is a function of both the urban and environmental ecosystems (UEE) and the current and future uses of the land according to the overall planning framework (PP).

- Evaluation of Nuisance Exposure Level (EL) of the receptors (e.g. population) in each homogeneous area of the territory. This step is implemented downstream of monitoring of the noise and odour levels representative of the area. 
- Definition of Nuisances Standard Limits (SL) for each homogeneous area of the territory according to National and Local laws;

- Estimation of the Potential Nuisance Impacts (PNI) for each homogeneous area of the territory according to S, EL and SL.

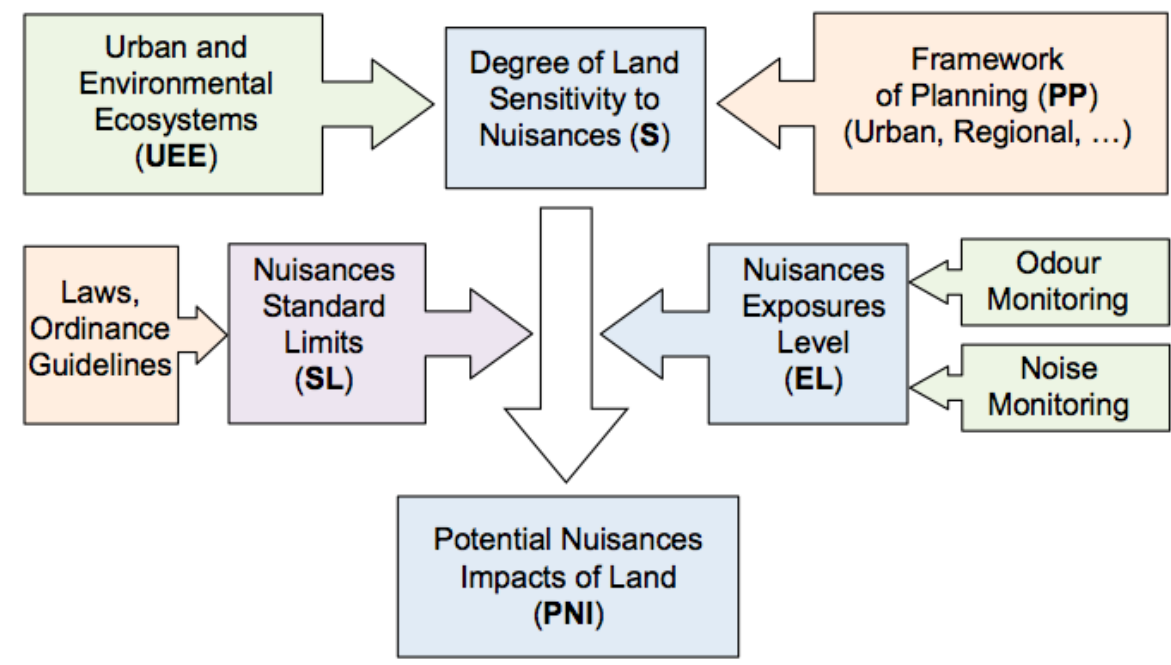

Figure 1. Framework for the definition of the Nuisance Action Plan

Definitions of common strategies to solve or mitigate nuisance impacts and protect quiet and healthy areas according to the potential PNI.

Degree of Land Sensitivity to Nuisances ( $\mathrm{S}$ ) is a function of the Urban and Environmental Ecosystems (UEE) according to the indicators reported in Table 3.

Table 3. Criteria and indicators for the assessment of the degree of Land Sensitivity to Nuisances (S).

\begin{tabular}{|c|c|c|c|c|}
\hline Criteria & & Indicator & Class & Score \\
\hline \multirow{5}{*}{ Strategic level } & \multirow{5}{*}{ LU } & \multirow{5}{*}{$\begin{array}{l}\text { Land use destination or class of } \\
\text { locations }\end{array}$} & Residential & 30 \\
\hline & & & City Centre & 20 \\
\hline & & & Commercial & 15 \\
\hline & & & Agricultural & 10 \\
\hline & & & Industrial & 5 \\
\hline \multirow{7}{*}{$\begin{array}{l}\text { Abundance of } \\
\text { Receptors }\end{array}$} & \multirow{3}{*}{ Rc } & \multirow{3}{*}{ Number of citizens } & High & 30 \\
\hline & & & Medium & 20 \\
\hline & & & Low & 10 \\
\hline & \multirow{2}{*}{$\mathrm{Rb}$} & \multirow{2}{*}{$\begin{array}{l}\text { Sensitive buildings (schools, hospitals, } \\
\text { Cemetery, etc.) }\end{array}$} & Presence & 10 \\
\hline & & & Absence & 0 \\
\hline & \multirow[b]{2}{*}{$\operatorname{Re}$} & \multirow{2}{*}{$\begin{array}{l}\text { Sensitive environmental location } \\
\text { (preserved area, National or regional } \\
\text { park, protected ecosystem, etc.) }\end{array}$} & Presence & 10 \\
\hline & & & Absence & 0 \\
\hline \multirow{4}{*}{$\begin{array}{l}\text { Environmental } \\
\text { Pressures }\end{array}$} & \multirow[t]{2}{*}{$\mathrm{Pn}$} & \multirow[t]{2}{*}{ Noise impacting sources } & $\begin{array}{l}\text { Presence of relevant sources (Airport, } \\
\text { Rail, Highways, Industry, et similar) }\end{array}$ & 0 \\
\hline & & & Absence of relevant sources & 10 \\
\hline & \multirow[t]{2}{*}{ Po } & \multirow[t]{2}{*}{ Odour impacting sources } & $\begin{array}{l}\text { Presence of relevant sources } \\
\text { (Wastewater Treatment Plant, Landfill, } \\
\text { Industry, et similar) }\end{array}$ & 0 \\
\hline & & & Absence of relevant sources & 10 \\
\hline
\end{tabular}

The degree of Land Sensitivity to Nuisances (S) will be expressed as percentages according to the following equation:

$$
S[\%]=\left[\left(L U+R_{c}+R_{b}+R_{e}+P_{n}+P_{o}\right) / 100\right]
$$


Each indicator assumes in relation of its class a score according to the assessment matrix reported in Table 3. To take into account the overall framework of planning (PP), the degree of Land Sensitivity to Nuisances is calculated in current scenario $\left(S_{0}\right)$ and compared with the planned scenario $\left(S_{p}\right)$.

For the estimation of the Potential Nuisance Impacts (PNI), it is necessary define Nuisances Standard Limits (SL). If noise limits are easily to identify according to the National standards and laws, in contrast, odour acceptability levels are not universally defined and regulations are generally still lacking. Several studies are trying to standardize odour impact limits and the European Union is ready for a standardization, with the definition of Nuisances Standard Limits (SL) subsequently being immediate.

\section{Conclusions}

The Urban Environment is a priority for world population, not least because so many live in cities. There is a contradiction in the urban equation, however. Urban areas drive economic development and deliver many public services, such as education, healthcare and transportation; but they are also associated with environmental degradation, congestion, economic and social exclusion.

To improve the quality of the urban environment has therefore become a major objective for policy makers. But making sure that urban policies are coherent is a challenge. There are many institutions both sectorial and territorial - with different aims, and policies are often carried out independently and with conflicting effects. The fact that urban issues are implemented locally while having a European or even global impact is also a big challenge.

Noise Action Plans are well defined throughout Europe, with there being several tools for their sustainable implementation reported in current literature. In contrast, there is no defined planning for odour emissions that often cause significant and negative impacts. Noise and odour annoyance have the same target receptors that could be managed under the same Action Plan. The framework of a Nuisance Action Plan was proposed as a prosecutable solution based on the degree of land sensitivity to nuisances. Nuisance acceptability levels are definable according to the sensitivity of the locations.

Further studies and efforts by the Authorities are needed to define odour limits. Factors related to vibrations and visual perception of the landscape could further contribute to controlling total sensorial annoyance in land planning.

\section{References}

Belgiorno V., Naddeo V. and Zarra T. (2012), Odour Impact Assessment Handbook, Wiley \& Son. London. ISBN: 9781-119-96928-0.

Bull M., Mclntyre A., Hall D., Allison G., Redmore J., Pullen J., Caird L., Stoaling M., Fain R. (2014), IAQM Guidance on the assessment of odour for planning. Institute of Air Quality Management, London.

de Ruiter E.P.J. (2009), A tool for environmental noise control in urban planning: the Population Annoyance Index. Proceeding of NAG/DAGA Conference, Rotterdam.

EN 13725:2003 (2003), Air Quality e Determination of Odour Concentration by Dynamic Olfactometry, Comité Européen de Normalisation, Brussels, 1 - 70.

European Directive 2002/49/CE of the European Parliament and of the Council relating to the assessment and management of environmental noise (END).

Giuliani S., Zarra T., Nicolas J., Naddeo V., Belgiorno V. and Romain A.C. (2012), An alternative approach of the enose training phase in odour impact assessment, Chemical Engineering Transactions, 30, 139-144.

Griffiths K.D. (2014), Disentangling the Frequency and Intensity Dimensions of Nuisance Odour and Implications for Jurisdictional Odour Impact Criteria, Atmospheric Environment, 90, 125-132.

Guski R., Felscher-Suhr U. and Schuemer R. (1999), The Concept of Noise Annoyance: How International Experts See It, Journal of Sound and Vibration, 223(4), 513-527. 
Kephalopoulos S., Paviotti M., Anfosso-Lédée F., Van Maercke D., Shilton S. and Jones N. (2014), Advances in the development of common noise assessment methods in Europe: the CNOSSOS-EU framework for strategic environmental noise mapping, Science of the Total Environment, 400-410.

Naddeo V., Zarra T., Giuliani S. and Belgiorno V. (2012a), Odour impact assessment in industrial areas, Chemical Engineering Transactions, 30, 85-90.

Naddeo V., Belgiorno V. and Zarra T. (2012b), Odour Characterization and Exposure Effects, Odour Impact Assessment Handbook, Wiley \& Son. London, ISBN: 978-1-119-96928-0, 7-29.

Nicell J.A. (2009), Assessment and regulation of odour impacts, Atmospheric Environment, 43, 196-206.

Sironi S., Capelli L., Dentoni L. and Del Rosso R. (2012), Odour Regulation and Policies in Odour Impact Assessment Handbook, Wiley \& Son. London. ISBN: 978-1-119-96928-0, 175-186.

Zarra T., Naddeo V., Belgiorno V., Reiser M. and Kranert M. (2008), Odour monitoring of small wastewater treatment plant located in sensitive environment, Water Science and Technology. 58(1), 89-94.

Zarra T., Naddeo V., Belgiorno V., Reiser M. and Kranert M. (2009a), Instrumental Characterization of Odour: A Combination of Olfactory and Analytical Methods, Water Science and Technology, 59(8), 1603-1609.

Zarra T., Naddeo V. and Belgiorno V. (2009b), A novel tool for estimating the odour emissions of composting plants in air pollution management, Global Nest Journal, 11(4), 477-486.

Zarra T., Naddeo V., Giuliani S. and Belgiorno V. (2010), Optimization of field inspection method for odour impact assessment, Chemical Engineering Transactions, 23, 93-98.

Zarra T., Giuliani S., Naddeo V. and Belgiorno V. (2012a), Control of odour emission in wastewater treatment plants by direct and undirected measurement of odour emission capacity, Water Science and Technology, 66(8), 1627-1633.

Zarra T., Reiser M., Naddeo V., Belgiorno V. and Kranert M. (2012b), A comparative and critical evaluation of different sampling materials in the measurement of odour concentration by dynamic olfactometry, Chemical Engineering Transactions, 30, 307-312.

Zarra T., Reiser M., Naddeo V., Belgiorno V. and Kranert M. (2014), Odour Emissions Characterization from Wastewater Treatment Plants by Different Measurement Methods, Chemical Engineering Transactions, 40, 37-42. 